Disclosure of Interests: None declared.

DOI: 10.1136/annrheumdis-2021-eular.3330

\section{POS1005 ASSESSMENT OF DAREA AND MODIFIED DAREA IN AN ARGENTINIAN-GUATEMALAN REACTIVE ARTHRITIS COHORT}

M. Benegas ${ }^{1}$, C. Orozco ${ }^{2}$, P. Giorgis ${ }^{2}$, E. E. Schneeberger ${ }^{2}$, J. M. Bande ${ }^{3}$, M A. Medina ${ }^{4}$, I. Iraheta ${ }^{5}$, C. Airoldi ${ }^{6}$, P. Girard Bosch ${ }^{7}$, S. Scarafia ${ }^{8}$, E. Velozo ${ }^{9}$, O. Rillo ${ }^{10}$, M. Guinsburg ${ }^{11}$, M. P. Cowan ${ }^{12}$, M. Piovesan ${ }^{12}$, V. Martire, L. Casalla ${ }^{12}$, V. Cosentino ${ }^{13}$, P. Gonzalez ${ }^{14}$, C. Peon ${ }^{14}$, R. Gomez ${ }^{14}$, A. Benitez ${ }^{14}$, M. J. Gamba ${ }^{14} .{ }^{1}$ Sanatorio Méndez, Reumatologia, CABA, Argentina; ${ }^{2}$ Instituto de Rehabilitación psicofísica, Reumatologia, caba, Argentina; ${ }^{3}$ Hospital tornú, Reumatologia, CAB, Argentina; ${ }^{4}$ Hospital tornú, Reumatologia, CABA, Argentina; ${ }^{5}$ Asociación Guatemalteca antienfermedades reumáticas, Reumatologia, Guatemala, Guatemala; ${ }^{6}$ Hospital Provincial de Rosario, Reumatologia, Rosario, Argentina; ${ }^{7}$ Instituto médico platense, Reumatologia, La plata, Argentina; ${ }^{8}$ Hospital Municipal de San Fernando, Reumatologia, Buenos Aires, Argentina; ${ }^{9}$ Sanatorio y Universidad Adventista del Plata, Reumatologia, Entre Rios, Argentina; ${ }^{10}$ Hospital Pirovano, Reumatologia, CABA, Argentina; ${ }^{11}$ Hospital Glassman, Reumatologia, Bahia Blanca, Argentina; ${ }^{12}$ Consultorio privado, Reumatologia, CABA, Argentina; ${ }^{13}$ Hospital Ramos Mejía, Reumatologia, CABA, Argentina; ${ }^{14}$ Hospital Alejandro Posadas, Reumatologia, Buenos Aires, Argentina

Background: Reactive Arthritis $(\mathrm{Re} A)$ is an inflammatory joint disease and, as in rheumatoid or psoriatic arthritis, composite indices are the most useful tools to measure disease activity. The Disease Activity Index for Reactive Arthritis (DAREA) is the only developed index for ReA, which requires a 66/68 joint count and CRP for its assessment, the latter being difficult to acquire in our setting. Therefore, we developed a simplified index, the modified DAREA (DAREAm), with a lower joint count and ESR for its evaluation.

Objectives: 1) To evaluate the DAREA and the DAREAm in a cohort of patients with diagnosis of $\mathrm{ReA}$ and post-infectious arthritis 2) To assess the correlation of the DAREA and DAREAm with several clinical variables, functional capacity and quality of life in a cohort of patients with ReA.

Methods: Patients with diagnosis of ReA (Calin'79) and post-infectious arthritis were included. Demographic data were collected, patient's pain and global assessment were evaluated through a visual analog scale (VAS) and a 3-point scale (no pain $=0$, mild $=1$, moderate $=2$, severe $=3$ ), physician's global assessment, morning stiffness (MS) and VAS fatigue. Functional capacity was assessed by $H A Q$ and quality of life according to EuroQol-5 dimensions (EQ-5D), and the activity indices DAS28, DAREA and DAREAm were calculated. Statistical analysis: a descriptive analysis of the variables and correlation between numerical variables with Spearman rank correlation were performed. Results: 57 patients were included, 53 with diagnosis of $\mathrm{ReA}$, the majority post urogenital $(63 \%)$ and gastrointestinal (17\%), and 4 with diagnosis of post-infectious arthritis. Fifty six percent were male, mean age: 40 years old $(S D \pm 14)$ and median ReA duration: 15 months (IQR 2-45). The number of painful and swollen joints in a 66/68 joint count showed a median of 2 (IQR 0-3) and 1 (IQR 1-2) respectively. Median VAS pain 43 (IQR 15-70), patient's disease activity 40 (IQR 20-60) and physician's 40 (IQR 20-60), MS 10 (IQR 0-50) and fatigue 30 (IQR 0-80). Median DAS28 3.6 (IQR 2.3-4.3), DAREA 7.4 (IQR 2.5-10.6), DAREAm 8.6 (IQR 4.6-12.7), HAQ 0.625 (IQR 0.125-1). The dimensions with the greatest compromise in the EQ-5D were pain/discomfort $(63 \%)$ and anxiety/ depression (51\%), and the median VAS EQ-5D was 60 (IQR 32-80). DAREA correlated with DAREAm ( $r s=0.89 ; p<0.001)$, DAS28 ( $r s=0.84 ; p<0.001)$, medical VAS $(r s=0.60$; $p<0.001)$, MS ( $r s=0,50 ; p<0.001), H A Q(r s=0.53 ; p<0.001)$, VAS fatigue ( $r s=0.57 ; p$ $<0.001)$ and mobility subscales of the EQ5D ( $r s=0.56$; $p<0.001)$, pain/discomfort $(r s=$ $0.49 ; p<0.001$ ) and anxiety/depression ( $r s=0.61 ; p<0.001$ ). The DAREAm correlated with DAS28 ( $r s=0.93 ; p<0.001$ ), physician VAS ( $r s=0.58 ; p<0.001)$, fatigue VAS $(r s=$ $0.53 ; p<0.001), \mathrm{HAQ}(\mathrm{rs}=0.51 ; \mathrm{p}<0.001)$ and the EQ5D subscales: mobility ( $r s=0.64 ; \mathrm{p}$ $<0.001$ ), pain/discomfort ( $r s=0.56 ; p<0.001)$ and anxiety/depression ( $r s=0.66 ; p<0.001$ ) Conclusion: This is the first study that assess activity indices in a cohort of patients with ReA. The DAREAm demonstrated a very good correlation with both DAREA and DAS28. We encourage the use of this simplified index in daily practice to evaluate patients with $R e A$. Disclosure of Interests: None declared.

DOI: 10.1136/annrheumdis-2021-eular.3374

\section{\begin{tabular}{|l|l}
\hline POS1006 & ABERRANT TH17 CELLS EXPANSION AND RISK \\
\hline
\end{tabular} FACTORS IN ANKYLOSING SPONDYLITIS PATIENTS COMPLICATED WITH CARDIOVASCULAR EVENTS}

T. Ding ${ }^{1}$, B. C. $\mathrm{LI}^{2}$, R. Su${ }^{2}$, X. F. LI' ${ }^{2}$, C. Wang ${ }^{2} .{ }^{1}$ The Second Hospital of Shanxi Medical University, Rheumatology, Taiyuan, China; ${ }^{2}$ Rheumatology, The Second Hospital of Shanxi Medical university, Taiyuan, China, Rheumatology, Taiyuan, China

Background: The incidence of Ankylosing Spondylitis (AS) complicated with cardiovascular diseases (CVD) has increased in recent years [1]. However, identification of risk factors indicating the development of CAD in AS patients is lacking. Th17 cells are increasingly recognized to be important in atherogenesis
[2]. However, the role of these cells in the pathogenesis of ankylosing spondylitis patients complicated with cardiovascular events remains elusive.

Objectives: This study aimed to assess the level of circulating Th17 cells as well as other lymphocyte subsets such as Treg, Th, Ts, and NK cells in AS combined with CVD, and further to evaluate whether elevations in special PBMC subpopulations in AS patients indicate an increased risk of CVD.

Methods: Samples were assessed from 141 AS patients hospitalized at the Second Hospital of Shanxi Medical University (60 AS patients combined with CVD and 81 AS patients without CVD) and 100 healthy controls. The absolute numbers of lymphocytes and CD4+ T cells in peripheral blood were determined using Flow Cytometer. The association between PBMC subpopulations and CVD development in AS patients were analyzed using multivariable logistic regression. Results: 1. Compared with AS group, AS with CVD group exhibited significant increases in the number of Th17 cells $(P=0.001)$ and Treg cells $(P=0.046)$. The ratio of Th17/Treg was also increased $(P=0.085)$.

2. Analogous increases in the absolute number $(P<0.001)$ and frequency $(P<0.001)$ of Th1 cells, as well as the ratio of Th1/Th2 $(P<0.001)$ and Th1/Treg $(P=0.004)$ were also present in AS with CVD patients, compared to those without CVD. 3. Compared to HCs, 141 AS patients showed significantly decreased Treg cells $(P<0.012)$ and increased Th17/Treg $(P=0.001)$.

4. Logistic regression showed age (odds ratio: $1.09 ; 95 \% \mathrm{Cl}: 1.035-1.137$ ), hypertension (odds ratio: $3.31 ; 95 \% \mathrm{Cl}$ : $1.152-9.528$ ), diabetes (odds ratio: $8.03 ; 95 \%$ $\mathrm{Cl}: 1.251-51.503$ ), and elevated level of Th1 number (odds ratio: $1.01 ; 95 \% \mathrm{Cl}$ 1.003-1.016) and DD (D-dimer) (odds ratio: 1.00; 95\% Cl: 1.000-1.002) were significantly correlated with the onset of CVD in AS patients.

5. Smoke, increased Th17 level, and use of NSAIDS were also positively correlated with the onset of CVD although the P-values did not reach significant. Conclusion: Our data indicates aberrant expansion of Th17 cells in AS with CVD patients. Moreover, age, hypertension, diabetes, and increased level of Th1 in PBMC and DD are single independent risk factors for the presence of CVD in AS. The mechanisms of atherogenesis in AS may associate with the elevations in Th1 and Th17 cells. Imbalance of Th1/Th2 and Th17/Treg may be shared etiologic pathways of AS and CVD, providing attractive targets for the prevention and therapy of CVD development in AS patients.

\section{REFERENCES:}

[1] Kim JH, Choi IA. Cardiovascular morbidity and mortality in patients with spondyloar thritis: A meta-analysis. Int J Rheum Dis (2020). doi: 10.1111/1756-185x.13970.

[2] Saigusa R, Winkels $H$, Ley K. T cell subsets and functions in atherosclerosis Nat Rev Cardiol. 2020 Jul;17(7):387-401. doi: 10.1038/s41569-020-0352-5.
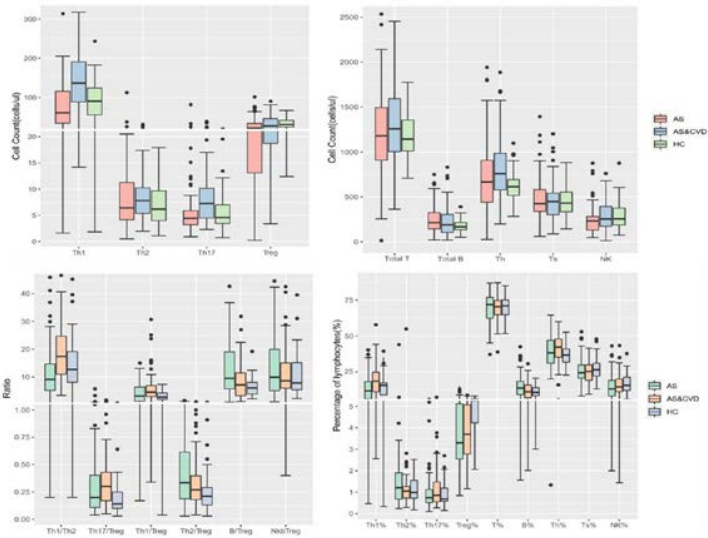

Figure 1. Compared with AS group, AS with CVD group exhibited significant increases in the number of Th17 cells $(P=0.001)$ and Treg cells $(P=0.046)$. The ratio of Th17/Treg was also increased $(P=0.085)$. The absolute number $(P<0.001)$ and frequency $(P<0.001)$ of $T h 1$ cells, as well as the ratio of Th1/Th2 $(P<0.001)$ and Th1/Treg $(P=0.004)$ were also present in AS with CVD patients.

Disclosure of Interests: None declared

DOI: 10.1136/annrheumdis-2021-eular.3442

POS1007

OPTIMIZING A REFERRAL STRATEGY FOR PATIENTS WITH A HIGH PROBABILITY OF AXIAL SPONDYLOARTHRITIS: THE ROLE OF AGE AND SYMPTOM DURATION

$\underline{\text { F. Proft }}{ }^{1}$, L. Spiller ${ }^{1}$, B. Muche ${ }^{1}$, M. Protopopov ${ }^{1}$, J. Rademacher ${ }^{1}$, V. Rios Rodriguez ${ }^{1}$, M. Torgutalp ${ }^{1}$, D. Poddubnyy ${ }^{1}$, I. Redeker ${ }^{2} .{ }^{1}$ Charité Universitätsmedizin Berlin, Division of Gastroenterology, Infectious Diseases and Rheumatology; Department of Rheumatology, Berlin, Germany; ${ }^{2}$ German Rheumatism Research Centre; Deutsches Rheuma-Forschungszentrum Berlin (DRFZ);, Programmbereich Epidemiologie, Beerlin, Germany

Background: One of the most important prerequisites for a timely diagnosis of axia spondyloarthritis (axSpA) is the early referral of a patient with back pain to a rheumatologist. In the past years a number of referral strategies has been proposed, 